\title{
Unidades de Polícia Pacificadora (UPPs) no Rio de Janeiro: uma história a partir das percepções e reflexões do gestor responsável por sua implantação
}

Joysi Moraes

Universidade Federal Fluminense

Sandra R. H. Mariano

Universidade Federal Fluminense

Andrea Marinho de Souza Franco

Universidade Federal Fluminense

\begin{abstract}
Neste artigo narra-se uma das possíveis histórias das Unidades de Polícia Pacificadora (UPPs) no Rio de Janeiro. Aqui, são destacadas as percepções e reflexões do gestor responsável por sua implantação, o secretário de Segurança Pública do Rio de Janeiro, José Mariano Beltrame. Por isso mesmo, foi utilizada a história oral, uma metodologia que privilegia a história do tempo presente através da narrativa pessoal dos sujeitos que participaram ou testemunharam o acontecimento em foco. Para apresentação e análise desta história das UPPs foi utilizado o Planejamento Estratégico Situacional (PES), um instrumento teórico-metodológico constituído de quatro momentos: explicativo, normativo, estratégico e tático-operacional. O PES, como instrumento metodológico, permitiu articular, de forma lógica, as falas do secretário de Segurança, analisando as ações desse gestor público em um contexto e tema específicos, evidenciando o jogo político e social ao longo do processo de construção de uma das principais políticas públicas do Rio de Janeiro, as UPPs. A reconstrução e a análise do momento da implantação dessa política deixam evidentes que a compreensão da dinâmica do jogo social e a vontade pessoal do gestor público são fundamentais para uma ação pública mais efetiva.
\end{abstract}

Palavras-chave: Unidades de Polícia Pacificadora (UPPs); Planejamento Estratégico Situacional (PES); Rio de Janeiro.

Unidades de la Policía Pacificadora (UPPs) en Rio de Janeiro: una historia que destaca las percepciones y reflexiones del responsable de su implementación

En este artículo se narra una de las posibles historias de la planificación de las Unidades de la Policía Pacificadora (UPPs). Se destacó las percepciones y reflexiones del responsable de su implementación,

DOI: http://dx.doi.org/10.1590/0034-7612121746

(c) BY-NC

Artigo recebido em 5 ago. 2013 e aceito em 19 set. 2014. 
José Mariano Beltrame, Secretario de Seguridad Publica de Río de Janeiro. Se utilizó la historia oral, una metodología que privilegia la historia en el tiempo presente a través de la narrativa de los sujetos que participaron o fueron testigos del acontecimiento en foco. Se utilizó la Planificación Estratégica Situacional (PES) para la presentación y análisis de esta historia. PES es una herramienta teórica y metodológica que consiste en cuatro etapas: explicativa, normativa, estratégica y táctica-operacional. La PES, como herramienta metodológica, ha permitido articular, de una manera lógica, las declaraciones del Secretario y analizó su actuación en un contexto y tema específico, destacando el juego político y social de la construcción de una de las políticas públicas más importantes de Río de Janeiro, las UPPs. La reconstrucción y el análisis del tiempo de la implementación es una evidencia de que la comprensión del juego social y la buena disposición del Secretario son esenciales para una acción pública más eficaz.

Palabras clave: Unidades de la Policía Pacificadora (UPPs); Planificación Estratégica Situacional (PES); Rio de Janeiro.

Police Pacification Units (UPPs) in Rio de Janeiro: a history from the perceptions and reflections of the manager responsible for its implementation

This paper shows one of the possible histories of the Police Pacification Units (UPPs) in Rio de Janeiro. It is highlighted the perceptions and reflections of the manager responsible for its implementation, José Mariano Beltrame, the Secretary of Public Security in Rio de Janeiro. It was used an oral history, a methodology that focuses on the present time through the narrative of the subjects that took part in the event or witnessed it. The Strategic Situational Planning (SSP) was used for the presentation and analysis of this story. SSP is a theoretical and methodological tool that consists of four stages: explanatory, normative, strategic and tactical-operational. The SSP, as a methodological tool, has enabled to articulate, in a logical way, the statements of the Secretary. It analysed the actions of the Secretary in a specific context and topic, highlighting the social and political game through the construction of one of the most important public policies in Rio de Janeiro, the UPPs. The reconstruction and analysis of the time of their implementation is an evidence that the understanding of the social game and the willingness of the Secretary are essential for a more effective public action.

Keywords: Police Pacification Units (UPPs); Strategic Situational Planning (SSP); Rio de Janeiro.

\section{Introdução}

A partir dos anos 1980, período conhecido como a "década perdida", a situação econômica do Rio de Janeiro passou por um processo de deterioração por uma confluência de fatores. Entre 1989 a 1992, seu produto interno bruto diminuiu 15\%. Entre 1991 e 1996 foram destruídos 180 mil empregos industriais no estado (Lessa, 2000). Esse processo de decadência econômica foi intensificado pela transferência de um grande número de empresas para outros estados e pelo fechamento de fábricas em áreas que se tornavam cada vez mais violentas.

O Complexo do Alemão, por exemplo, uma das áreas mais violentas da cidade, formado por um conjunto de 12 favelas, localizado na zona norte da cidade, abrigava diversas indústrias que fechavam à medida que a violência aumentava. As favelas que hoje compõem o Complexo do Alemão, até os anos de 1980, eram apresentadas como bairros onde estava lo- 
calizado o principal polo industrial da cidade. Todavia, nos anos 1990, com os índices de violência aumentando, aliados à crise econômica daquele período, estima-se que foram fechados cerca de 20 mil postos de trabalho apenas naquela região. Com o fechamento das indústrias, aos poucos a área foi adquirindo uma nova configuração, as pessoas passaram a viver em situação de extrema pobreza ou miséria absoluta e, finalmente, o tráfico tomou conta da região a ponto de inviabilizar a presença do Estado (Oliveira, 2010:1567). Histórias semelhantes a essa se repetiram em muitas comunidades pobres do Rio de Janeiro, especialmente, aquelas situadas nos morros que compõem a geografia da cidade.

A progressiva deterioração das condições políticas e econômicas da cidade exacerbou a violência urbana que teve seu ápice na década de 1990. O Rio de Janeiro adquiriu o perfil de uma cidade violenta e, com a escalada da violência policial, a cidade foi dominada pela "metáfora da guerra" (Leite, 2000:73).

Enfim, se definiu uma separação entre o asfalto (a planície) e a favela (o morro). No asfalto, vivia a classe média, pessoas percebidas pela polícia como cidadãos que merecem a proteção do Estado, mas que se encontravam prisioneiros em suas próprias casas, ameaçadas pela população da favela, onde os moradores tinham direito a apenas uma "subcidadania" (Leite, 2000). Pelo menos, aparentemente, a presença do Estado nas favelas não era permitida pelas facções criminosas e milícias e, nas raras vezes em que ocorria, se dava por meio de inserções militares com soldados altamente armados.

Com objetivo de recuperar para o Estado os territórios empobrecidos, dominados pelo narcotráfico e milícias, o Estado está buscando se fazer presente em territórios em que antes era impedido de entrar. Essa inserção tem acontecido, desde novembro de 2008, por meio das Unidades de Polícia Pacificadora (UPPs) e é sobre o momento da implantação destas UPPs que trataremos neste artigo. Para tanto, analisamos a história das UPPs no Rio de Janeiro, a partir das percepções e reflexões do gestor responsável por sua implantação, o secretário de Segurança Pública do Rio de Janeiro, José Mariano Beltrame. Para apresentação e análise desta história das UPPs foi utilizado o planejamento estratégico situacional (PES), um instrumento teórico-metodológico que permitiu articular, de forma lógica, as falas do secretário de Segurança, analisando as ações desse gestor público em um contexto e tema específicos, evidenciando o jogo político e social ao longo do processo de construção de uma das principais políticas públicas do Rio de Janeiro, as UPPs.

\section{Metodologia}

Foi utilizada a história oral, uma metodologia que privilegia a história do tempo presente mediante a narrativa dos sujeitos que participaram ou testemunharam acontecimentos, como forma de se aproximar do objeto de estudo e que permite recuperar aquilo que não é encontrado em documentos de outra natureza (Alberti, 1990:22; Cappelle, Borges e Miranda, 2010:5). Esse método permite analisar a história sob a ótica dos atores que participaram de forma direta ou indireta da sua construção, no caso, da criação e planejamento das UPPs. 
A história oral ainda pode ser dividida em três gêneros ou modalidades distintas: a história oral de vida, a tradição oral e a história oral temática. Na primeira, o entrevistado tem autonomia para narrar livremente sobre sua experiência pessoal. Na tradição oral, o foco é a preservação da sabedoria dos ancestrais, da cultura, da visão de mundo de comunidades que podem se manifestar pela transmissão geracional. Na história oral temática, utilizada como metodologia nesta pesquisa, há maior objetividade: o sujeito da pesquisa fala sobre um assunto específico e preestabelecido. Nesse tipo de história oral, busca-se o esclarecimento ou opinião do entrevistado sobre um fenômeno contemporâneo (Bom Meihy, 1996).

O processo de investigação é composto de três etapas: a pré-entrevista, que corresponde à fase de preparação do encontro com o entrevistado; a entrevista, momento de gravação das falas dos entrevistados e de intervenção do pesquisador com perguntas que considerar necessárias para compreender melhor os detalhes do que está sendo contado; e a pós-entrevista, o encerramento da gravação e procedimentos para garantir a segurança do material obtido. Nesta última etapa está incluída a textualização, que trata da reorganização do discurso obedecendo à estruturação requerida para um texto escrito, onde a "voz" do entrevistador é suprimida para tornar o texto mais agradável e fluido (Bom Meihy, 1996). As falas consideradas mais relevantes para a compreensão do processo de criação e planejamento das UPPs podem ser observadas a seguir.

Para apresentação e análise da história das UPPs, na perspectiva do gestor responsável por sua implantação, uma vez que a história oral parte da narrativa pessoal do sujeito que participou do fenômeno em pauta, foi utilizado o PES. Segundo Matus (1993), o PES é um instrumento metodológico constituído de quatro momentos (explicativo, normativo, estratégico e tático-operacional) que permitem analisar o jogo político, econômico ou social ao longo do processo de construção das estratégias políticas e/ou definição de políticas e operações no âmbito do governo, exatamente, a partir da observação e/ou análise da construção desses quatro momentos.

Artmann (2000:8), ainda, destaca que "o conceito de momento, formulado para superar a ideia de 'etapas', muito rígida, implica numa visão dinâmica do processo (...). Assim, cada um desses momentos possui suas ferramentas metodológicas específicas, que podem no entanto, ser retomadas" sempre que necessário.

\section{Planejamento estratégico situacional (PES)}

O PES é um método e uma teoria do planejamento estratégico público, formulada por Carlos Matus, a partir de décadas de experiência na administração pública na América Latina. No PES, os temas são os problemas públicos, embora também seja aplicável a qualquer órgão cujo centro de jogo não seja exclusivamente o mercado, mas o jogo político, econômico e social (Matus, 1996:23).

Nas palavras do próprio Matus (1996:13), “o PES é um corpo teórico-metodológicoprático muito sólido, sistemático e rigoroso". A partir da utilização do PES é possível analisar 
as ações do gestor público em um determinado contexto e com um problema específico. Segundo De Toni (2007:6), sendo o PES um método e uma teoria, “o sujeito que planeja está incluído no objeto planejado". Nesse caso, o PES, além de ser "uma mediação entre o presente e o futuro", também é o método de análise do próprio plano e dos caminhos adotados pelo gestor público que o utiliza.

O enfoque proposto de planejamento, portanto, não é um rito burocrático ou um conhecimento que possa ser revelado a alguns e não a outros, mas uma capacidade pessoal e institucional de governar - que envolve, a um só tempo, perícia e arte —, de fazer política no sentido mais original deste termo. O processo de planejamento não substitui a perícia dos dirigentes, ao contrário, aumenta sua eficácia porque coloca estes aspectos a serviço de um projeto político coletivo. (...) Por isso mesmo, os principais momentos do PES tendem a utilizar instrumentos metodológicos parecidos. (De Toni, 2007:4 e 9)

O PES trabalha com dois conceitos básicos: o de situação e o da teoria da produção social que, também, explicam os instrumentos metodológicos. "Situação significa o lugar social onde está situado o ator e a ação. Fundamentando a premissa da existência de uma pluralidade explicativa da situação de acordo com o número de atores envolvidos" (Lana e Gomes, 1996:106). A teoria da produção social sustenta que a explicação situacional dos problemas deve ser feita em dois planos inter-relacionados: plano da produção dos fatos, tal qual são percebidos na superfície; e plano das essências ou das estruturas determinantes dos fenômenos, que envolve o conhecimento das formas de acumulação de poder e das leis básicas que regulam uma formação social e que a determinam em última instância.

Nesse caso, o PES, que toma como fundamento a própria realidade, parte do princípio de que é possível traçar um plano, mas que não é possível escolher as circunstâncias em que ele será realizado. Em outros termos, o PES leva em conta que os participantes de um jogo social não têm comportamentos previsíveis e buscam maximizar o uso dos limitados recursos que possuem, a fim de aumentá-los a cada nova jogada. Isso significa que nenhum jogador pode raciocinar de modo determinístico. Nesse caso, a posição do gestor público é uma entre tantas outras no jogo e não é tomada como certa.

Segundo Matus (1993), se o gestor público deseja alcançar bons resultados, ele deve aprender a jogar no jogo social, o que significa jogar bem no dia a dia, medir-se com os outros jogadores e tentar dominar a tensão que o jogo produz numa situação concreta. No PES, o ator que planeja, em um jogo social, também é um jogador disputando espaço, recursos e influência, como qualquer outro, por mais poderoso e influente que ele seja. O gestor público, portanto, deve estar preparado para quatro problemas: saber explicar a realidade do jogo; saber delinear propostas de ação em condições de incerteza; saber pensar estratégias para lidar com os outros jogadores e com as circunstâncias, para calcular bem o que é possível fazer, em cada momento, em relação ao que é possível fazer para alcançar os objetivos; e saber fazer, no momento oportuno, e com eficácia, recalculando e completando o plano com um complemento de improvisação subordinada (Matus, 1991). 
Desse modo, o PES pode ser sintetizado em quatro perguntas que organizarão e orientarão a elaboração do próprio plano e que retomam os quatro problemas já citados: como explicar a realidade? Como conceber um plano? Como tornar viável o plano necessário? Como agir a cada dia de forma planejada? Essas perguntas correspondem a quatro momentos do PES: explicativo, normativo, estratégico e tático operacional. Mas que fique claro: "os momentos não podem ser vistos ou tratados como etapas. Portanto, devem ser visualizados como uma espécie de espiral, não como uma sequência ou algo gradual" (Adum e Coelho, 2007:5). É preciso lembrar que a realidade não segue uma sequência predeterminada, como já assinalado por Artmann (2000); o conceito de momento, nesta metodologia, implica uma visão dinâmica do processo de planejamento, que se caracteriza pela permanente interação dos momentos e pela constante retomada dos mesmos.

O momento explicativo é de reconhecer que existem várias explicações verdadeiras sobre uma mesma realidade e que as explicações de jogadores adversários não são iguais porque cada explicação sobre a realidade depende de quem explica. Nesse caso, o planejador, que também é um jogador, precisa considerar que não resolverá o problema das várias explicações ao afirmar que uma delas é verdadeira e que as outras são falsas. Mas como planejar em meio a tantas verdades?

Para Matus (1996), tanto melhor será o planejador, nesse caso, o gestor público, quanto maior for sua capacidade de compreender o jogo e os diversos interesses dos jogadores. Interessa conhecer, portanto, a explicação dos que competem ou cooperam com o planejador porque com esse conhecimento ele pode jogar melhor. Mais assertivo será o planejador quanto mais entender os demais participantes do jogo. Entender o outro jogador não significa dar-lhe razão, tampouco ceder. Significa compreender a "posição" do outro no jogo, entender a "chave" com a qual ele lê sua realidade e a dos demais jogadores.

Há que se destacar que o PES concentra-se em problemas, o que significa: explicar como nasce e se desenvolve um problema; fazer planos para atacar as causas do problema mediante operações; analisar a viabilidade política do plano ou verificar o modo de construir sua viabilidade; e atacar o problema na prática, realizando operações planejadas. Por isso, para o PES, o primeiro passo é a descrição do problema com uma enumeração de fatos que mostram que o problema realmente existe.

O momento normativo é o de concepção do plano, de identificação de quais ações poderiam ser postas em prática para enfrentar os problemas. Esse é o momento de seleção das operações e ações possíveis e necessárias para atingir os objetivos (Matus, 1993). O plano adquire a forma de propostas de decisão que devem ser tomadas a partir da situação inicial percebida. O momento normativo implica um cálculo aproximado dos resultados. Para tanto, é preciso reconhecer a existência de incerteza e surpresas, trabalhando com cenários, planos de contingência e outros métodos apropriados, ou seja, reconhecendo a força da ação dos outros atores sociais envolvidos. Deste modo, o PES leva em consideração uma determinada situação-objetivo que está condicionada a um cenário e à possibilidade de ocorrências de outros porque a realidade não é previsível. 
Isto significa que o gestor público deve reconhecer que há uma assimetria entre passado e futuro. O passado está encerrado; o futuro está aberto a muitas possibilidades e não podemos imaginá-las todas. Só é possível enumerar as possibilidades futuras, nunca todas; e não se pode atribuir probabilidades. Quantas e quais as possibilidades a serem enumeradas dependem do analista (planejador), de sua imaginação, experiência e conhecimentos sobre a situação. E, ainda assim, a enumeração será sempre incompleta e haverá sempre o risco. Assim, de acordo com Matus (1996:64), "o plano é uma aposta e, para algumas mentalidades amestradas, isso parece como falta de sistematização". Mas o plano é uma aposta porque seu resultado não depende somente do próprio plano. Depende, também, das circunstâncias que não são controláveis e nem possíveis de predizer.

O momento estratégico é o de analisar a viabilidade do plano, de descobrir o "que poder ser feito" e "como fazer", de buscar identificar estratégias que poderão ser utilizadas. No PES, é necessário considerar as possíveis estratégias em função do comportamento dos demais atores e das capacidades envolvidas. Deve-se considerar, portanto, as relações de poder, o poder político, os conhecimentos, as capacidades organizativas e os recursos dos atores sociais envolvidos. Ao considerar as relações de poder, o planejador distingue a parte do plano que está sob sua governabilidade da parte que requer a cooperação de outros atores para alcançar os objetivos pretendidos.

O momento estratégico, portanto, inclui a análise de viabilidade do plano em três níveis: da viabilidade política, que trata das estratégias de cooperação que supõe negociações para acordar vias comuns de ação por meio de renúncias recíprocas, onde um ator ganha a adesão do outro à sua própria posição e onde o conflito serve de campo para os atores mensurarem o peso de seus projetos; da viabilidade econômica, que deve responder se os projetos políticos, econômicos e organizativos são viáveis economicamente; e da viabilidade institucional-organizativa, que terá de responder se a capacidade organizativa é capaz de sustentar o programa proposto, se há capacidade de melhorar a organização institucional e se a organização desenhada para cumprir o plano é viável e eficaz (Lana e Gomes, 1996).

O momento tático-operacional, cujo ponto-chave consiste em compreender que o planejamento é o resultado de uma mediação entre o conhecimento e a ação, é o momento de implantação e execução do plano, de mobilização dos recursos necessários. Trata-se de "recalcular o plano e de aprimorá-lo de acordo com as circunstâncias do momento da ação e do detalhe operacional que a prática exige" (Matus, 1996:104). Assim, o plano é realinhado e aprimorado de acordo com as circunstâncias do momento da ação e do detalhe operacional que a prática exige.

Em outros termos, a essência do PES é o acompanhamento permanente da realidade e a avaliação dos resultados das decisões tomadas e preteridas, com objetivo de verificar se os resultados produzidos estão na direção dos resultados esperados. Nesse caso, o papel do gestor público que planeja, na perspectiva do PES, é o de um sujeito que compreende a situação na qual está inserido, ou seja, o lugar social onde está e os atores envolvidos e, a partir da análise da situação, verifica qual a melhor ação a ser concretizada em determinado momento. Para Matus (1991, 1996), esse tipo de gestor público, capaz de compreender a dinâmica da situação, 
os interesses dos diversos jogadores e o momento de agir, é capaz de compreender que a mesma situação não se repete. Portanto, não há fórmula mágica para alcançar os resultados pretendidos, mas um gestor público atento à situação na qual está inserido e que busca atuar em parceiras e respeito à capacidade organizativa dos demais atores.

Para Matus (1996:74), “o ponto-chave do PES consiste em entender que o planejamento resulta de uma mediação entre o conhecimento e a ação". As respostas às três primeiras perguntas, que correspondem aos primeiros momentos, apontam para os métodos de acumular conhecimentos antes de agir, ou seja, correspondem aos momentos explicativo, normativo e estratégico. Metodologicamente, estes três primeiros momentos dizem respeito à dinâmica do processo que trata do acúmulo de conhecimento sobre determinado problema.

Assim, quando um problema passa por esses três momentos, ele apenas muda o conhecimento que o gestor público tem sobre ele, mas a realidade ainda continua à espera de uma ação. Daí a importância da mediação entre conhecimento acumulado nos três primeiros momentos mencionados e o quarto momento, a hora de agir. O momento quatro é, exatamente, o tático-operacional. Trata da ação de suporte ao plano. Seu propósito é criar um processo contínuo, sem rupturas, entre os três momentos anteriores e a ação diária. É esse processo de articular conhecimento e ação que caracteriza a metodologia do PES. Trata-se do recálculo do plano e do seu refinamento às circunstâncias do momento da ação e ao detalhe operacional que a prática exige (Matus, 1996). Exatamente, por isso, o PES é uma espécie de espiral e não uma sequência ou algo gradual (Adum e Coelho, 2007).

Dessa maneira, a seção a seguir apresenta como esses momentos foram articulados, pois é essa articulação que caracteriza o PES como método e teoria, a partir das falas do gestor responsável pela implantação das UPPs no Rio de Janeiro.

\section{O PES como instrumento de articulação lógica das falas do gestor responsável pela implantação das UPPs no Rio de Janeiro'}

As primeiras incursões para descobrir como se deu o nascimento das UPPs foram às publicações de periódicos acadêmicos e da mídia de massa. Nas principais bases de periódicos acadêmicos foram encontrados 30 artigos que tratavam da questão da pacificação em áreas em guerra civil e/ou militar em países governados por ditadores ou em regiões muito pobres, como partes da África. Na mídia de massa foram encontradas reportagens que mencionavam as experiências de segurança pública em grandes eventos no Rio de Janeiro como acontecimentos que foram propulsores das UPPs, em especial os Jogos Pan-Americanos, que aconteceram no Rio de Janeiro, em 2007. A partir de então, começou-se a buscar as pessoas envolvidas com a segurança dos Jogos Pan-Americanos.

A primeira entrevistada foi a tenente-coronel Claudete Lehmkuhl, da Polícia Militar de Santa Catarina desde 1983, estudiosa de políticas públicas de segurança pública, convocada

\footnotetext{
${ }^{1}$ As falas dos entrevistados estão em itálico para destacá-las ao longo do texto.
} 
pelo Ministério da Justiça (MJ). Segundo a tenente-coronel Lehmkuhl, o MJ, inicialmente, entrou em contato com os estados e solicitou o acesso aos bancos de dados dos policiais para identificar aqueles cujos currículos mostrassem conhecimento sobre a área de segurança pública, especialmente que trabalhassem com segurança pública que envolvesse o cidadão como corresponsável pela segurança da comunidade. Assim, chegaram a ela.

Segundo Lehmkuhl, a história das UPPs começou com o levantamento das demandas para os Jogos Pan-Americanos. A tenente-coronel Lehmkuhl

verificou que o Programa das Nações Unidas para o Desenvolvimento (Pnud) e a Federação das Indústrias do Estado do Rio de Janeiro (Firjan) já haviam realizado um levantamento da situação do Rio de Janeiro para desenvolver um projeto piloto no Rio: um projeto de segurança cidadã, de polícia comunitária.

A ideia era ter uma cidade segura para receber os atletas e a comunidade internacional, em 2007.

Os Jogos Pan-Americanos foram marcados por uma iniciativa inovadora, pois o MJ, através da Secretaria Nacional de Segurança Pública (Senasp), foi o órgão encarregado de organizar e coordenar a segurança do evento. Historicamente, a segurança de grandes eventos era de responsabilidade das Forças Armadas. O que levou a Presidência da República a optar por deixar a segurança sob a responsabilidade do MJ foi a ideia de aliar um conjunto de ações preventivas às tradicionais atividades de contenção da polícia, para garantir a Segurança dos Jogos Pan-Americanos. (tenente-coronel Lehmkuhl)

Para operacionalização desta segurança na cidade do Rio de Janeiro foram criados alguns programas desenvolvidos em parceria com organizações da sociedade civil, tais como representantes da indústria, das comunidades próximas aos locais onde aconteceram os jogos e parceiras com as próprias instituições públicas dos governos federal e estadual. Entre as principais agências implementadoras que trataram da operacionalização dos programas estavam a Firjan, o Serviço Social da Indústria (Sesi/RJ), o Serviço Nacional de Aprendizagem Industrial (Senai/RJ) e o Serviço de Apoio às Micro e Pequenas Empresas (Sebrae/RJ). Também foi firmada uma Carta Acordo com a Central Única de Favelas (Cufa), com o objetivo de oferecer às lideranças comunitárias cursos de capacitação. A Cufa, por sua vez, faria a mediação entre as organizações implementadoras (Senasp, lideranças comunitárias, Ministério Público do Estado do Rio de Janeiro, Defensoria Pública do Estado do Rio de Janeiro, Secretaria de Estado de Assistência Social e Direitos Humanos e Instituto de Segurança Pública do Rio de Janeiro) (Lehmkuhl, 2010:2-3).

De acordo com Moema Freire (entrevistada da Unidade de Políticas Sociais do Pnud), o governo brasileiro se inspirou em um projeto concretizado em Bogotá (Colômbia) para estabelecer um novo modelo de segurança pública. Multiplicadores, principalmente, representantes da polícia fluminense, foram conhecer a experiência in loco e participar de treinamentos naquele país. 
Esse conceito de Segurança Cidadã, de Polícia Comunitária, é muito inspirado na experiência de Bogotá, de Medellín. A ideia de ter uma cidade segura, na época, era porque nós não queríamos repetir o cenário da Rio 92. Os tanques nas ruas, as pessoas amedrontadas, soldados do exército nas descidas dos morros cariocas e as entradas da cidade e os locais dos eventos guardados por tanques de combate do exército. Nós não queríamos repetir este cenário nos Jogos Pan-Americanos. Era preciso envolver a população na segurança pública. Tudo com apoio da Firjan, principalmente os eventos, para que pudéssemos trabalhar mais próximo da população carioca. (Moema Freire)

A participação da Firjan é uma das questões que sempre aparece quando o assunto abordado é a segurança pública: "o que é que a Firjan tem a ver com a segurança pública?" Respondendo a esta pergunta, Andrea Marinho (Diretora de Educação da Firjan) afirma que,

em 2006, a Firjan fez um mapa de desenvolvimento porque a situação estava um desespero. A gente não tinha mais representação empresarial no Rio. As poucas empresas que ficaram transferiram o escritório para São Paulo. O Rio estava se tornando uma das cidades mais violentas do mundo e afastando as empresas. Era preciso fazer alguma coisa para trazê-las de volta.

O Mapa do Desenvolvimento do Estado do Rio de Janeiro, ao qual se refere a Diretora de Educação da Firjan, é o planejamento do Sistema Firjan. Nesse Mapa, essa organização busca construir uma visão estratégica compartilhada para o estado do Rio de Janeiro, com o alinhamento das lideranças empresariais em torno de indicadores, metas e ações estratégicas para cada 10 anos, na época, 2006-15. Esse mapa é um documento que apresenta propostas concretas dos empresários para a solução dos principais problemas do estado, agrupados em 13 temas estratégicos. A ideia é que a cada 10 anos todas as propostas sejam detalhadas e encaminhadas às principais lideranças políticas do estado e do país, incluindo os candidatos ao governo estadual e à presidência da República, como aconteceu nas eleições 2006. As propostas apresentadas, como as do Mapa 2006-2015, são resultado de debates e estudos de mais de mil empresários das mais diferentes áreas e regiões do estado, de especialistas renomados, das universidades, das autoridades públicas e da equipe técnica da Firjan que, juntos, identificaram as bases necessárias ao desenvolvimento, estabeleceram focos de atuação e apresentaram soluções (Sistema Firjan, 2006).

Como representantes do poder público de diversas áreas do estado participam da confecção desse mapa do estado, é muito comum perceber a presença da Firjan buscando colaborar com a concretização das proposições do estado do Rio de Janeiro. Nas comunidades já pacificadas, por exemplo, a Firjan tem apoiado ações de educação e profissionalização de jovens e adultos ou, mesmo, atuado diretamente mediante iniciativas do próprio Sistema.

É preciso lembrar que, em 2007, o governo federal, através do Ministério da Educação, colocou em pauta a proposta de um novo uso dos recursos do sistema da indústria para educação. Especificamente, a ideia era reorganizar a administração e o uso das verbas do Sistema S (Sesi, Senai, Sesc, Sebrae e outros), o que significava que as próprias federações das indústrias em cada estado, como no caso da Firjan, teriam que repensar o uso dos recursos oriundos 
da arrecadação compulsória de 2,5\% sobre a folha de salários das empresas, em que 1,5\% é destinado aos serviços sociais e 1\% à educação; ou seja, 60\% do montante são destinados aos serviços sociais e 40\% à educação (Fonseca, 2008).

Em outros termos, a proposta inicial do governo federal era transferir o recurso destinado à educação, administrado pelo Sistema S, para a gestão direta do Ministério da Educação. Assim, ao invés do Sistema S, o governo federal passaria a administrar a soma arrecadada. Todavia, após os debates entre Confederação Nacional da Indústria (CNI), Ministério da Educação (MEC), Ministério do Trabalho e Emprego (MTE), Ministério da Fazenda (MF), Serviço Nacional de Aprendizagem Industrial (Senai) e Serviço Social da Indústria (Sesi) ficou acordado, como primeira ação, que o Sistema S utilizasse parte dos recursos arrecadados para financiar mais vagas gratuitas na sua própria rede de ensino, bem como colaborasse com a formação dos profissionais da área de educação, como dos gestores das escolas públicas em colaboração com os estados (MEC, 2008:2).

No dia 28 de maio de 2014, por exemplo, em outra ação, o "Sistema Sesi/Firjan inaugurou a 13a Indústria do Conhecimento do projeto Sesi Cidadania em comunidades pacificadas do Rio. O espaço contará com uma biblioteca com acesso a internet e fica localizado no Casarão dos Prazeres, no alto do Morro dos Prazeres, em Santa Teresa” (Batista, 2014:1). O programa Indústria do Conhecimento, lançado em 2010, é mais uma parceira entre o Sistema S e o governo, desta vez, municipal, e tem como objetivo de oferecer suporte ao processo de desenvolvimento socioeconômico e cultural das comunidades pacificadas (UPPs).

São amostras claras de parcerias estabelecidas entre o governo federal e a Confederação Nacional da Indústria, cujo representante local é a própria Firjan, o que significa que esta deve buscar parcerias com o governo local, estadual e municipal. Portanto, a tendência é que, cada vez mais, a Firjan se sinta confortável para planejar com e para o estado do Rio de Janeiro, inclusive, sendo convidada para tanto, pois estará atendendo não só às demandas do governo estadual ou municipal, mas, principalmente, às demandas do governo federal.

A fala do presidente da Firjan (Eduardo Eugênio) também é bastante elucidativa:

eu acho que o governo no início não entendeu o que é que a gente queria fazer. Mas nossa agenda também era de interesse público. A classe empresarial também faz parte da população fluminense, gera empregos, recursos para o Estado. Era preciso fazer alguma coisa. E começamos por apoiar as iniciativas que focavam na segurança pública. Nós colocamos nosso pessoal à disposição para capacitar, negociar, financiar.

Essas iniciativas que garantiram a segurança pública nos Jogos Pan-Americanos mostraram novas possibilidades à Secretaria de Segurança Pública do Rio de Janeiro. Mas também foram medidas paliativas, pois a violência após os jogos continuou a mesma e, em determinadas regiões, até piorou.

Conhecer o que já tinha sido realizado, em termos de tentar tornar a cidade do Rio de Janeiro mais segura, representou um esforço didático de contextualizar a própria cidade e seus problemas, antes do período de gestão do secretário Beltrame. Conhecer essa história 
também foi uma espécie de preparo para a entrevista com secretário de Segurança Pública. Mas, logo no primeiro momento da entrevista, quando foi feita uma pergunta mais ampla para iniciar a conversa, ou seja, "como aconteceu a implantação das UPPs aqui no Rio de Janeiro?”, o secretário já foi afirmando que:

primeiro, eu acho que toda a sociedade carioca sabia que tinha que ser feito. Os estudiosos, os governantes, todos sabiam que o que tinha que ser feito era entrar nessas áreas e ficar. Muita gente pergunta: "Isso é a teoria das janelas quebradas de Nova York? Isso foi feito na Colômbia? Você copiou da Colômbia?". Não, se tem uma coisa que é carioca, são as UPPs. Agora, o que se planejou foi o seguinte: como que você vai entrar e ficar? Como é que você vai fazer isso?

Logo na primeira fala do secretário ficou claro que o método adequado para analisar a implementação das UPPs no Rio de Janeiro seria o PES. "O PES é um método que pressupõe constante adaptação a cada situação concreta onde é aplicado” (De Toni, 2007:9). Por isso mesmo, não é possível replicar o que foi feito em outro contexto, como no caso de Nova York, Colômbia ou, mesmo, no Rio de Janeiro nos anos anteriores. Eram condições diferentes, principalmente, com outros atores estratégicos nos cargos de gestão do governo estadual.

Como lembra De Toni (2007:11), o PES é, antes de tudo, "um potente enfoque metodológico, com princípios e visões filosóficas sobre a produção social, a liberdade humana e o papel dos governos, governante e governados". A análise de problemas de um contexto específico, a identificação de cenários, a visualização de outros atores sociais que podem influenciar na dinâmica do processo e do cenário, a ênfase na análise estratégica são elementos fundamentais que diferenciam o PES de outros métodos.

Isso não significa ignorar o passado. Ao contrário, significa reconhecer que é preciso outra abordagem. Como dito, o PES é composto por quatro momentos. Conhecer o histórico da cidade do Rio de Janeiro e reconhecer que as medidas utilizadas, até então, foram paliativas e de curta duração, bem como conhecer os motivos dos insucessos de tais medidas faziam parte dos três primeiros momentos do PES, ou seja, de acumular conhecimento e de conhecer os outros jogadores, nos ambientes interno (demais gestores públicos) e externo (principais atores nas comunidades, por exemplo). Foi esse acúmulo de conhecimento que permitiu ao secretário Beltrame identificar o tipo de ação a ser desenvolvida naquele momento.

Em 2007, ano que José Mariano Beltrame, sujeito que destacamos neste artigo, assumiu o cargo de secretário de Segurança Pública do Estado do Rio de Janeiro (SSP/RJ), a violência na cidade estava adquirindo novas facetas com as disputas, entre os principais grupos do tráfico, pelo domínio de territórios nos morros cariocas.

Quando fui convidado para ser Secretário de Segurança Pública, formei uma equipe e comecei a pensar com esta equipe sobre como é que poderíamos fazer a diferença no Rio de Janeiro e não apenas passar uma temporada no cargo. Foi, então, que começamos a analisar os índices de criminalidade da cidade. Eles estavam, obviamente, ligados à violência dentro das áreas dos morros. Nessas áreas, a quantidade de armas era enorme e as disputas entre diferentes facções de traficantes e, também 
com as milícias, impedia a polícia militar de subir o morro e entrar nas favelas. Nesses lugares o que existia era uma ditadura na qual os criminosos resolviam tudo como se fossem o poder judiciário. (Beltrame, SSP/RJ)

Assinala-se que, para começar, quando questionado sobre as experiências de segurança pública já realizadas no Rio de Janeiro para conter a violência, o secretário afirmou que as estudou para compreender os erros e acertos.

Acho que as pessoas não perceberam que a cidade do Rio de Janeiro é como se fosse um tabuleiro de xadrez. Nós vimos o que já tinha sido feito, mas a inspiração para as UPPs não foi a experiência de Medellín (Colômbia). A inspiração foi o tabuleiro de xadrez. O Rio de Janeiro é o tabuleiro de xadrez. Eu tenho os quadrinhos pretos e os quadrinhos brancos. A minha ideia era deixar tudo de uma cor só. Nem tudo preto, nem tudo branco, mas misturar as cores. Então eu e minha equipe tínhamos que responder uma pergunta: "como é que a gente faz para misturar as cores?"; a ideia não era acabar com a favela, mas acabar com a tirania que tinha ali dentro, imposta pela arma do comando do tráfico e das milícias. Era uma zona de guerra onde traficantes e milícias determinavam quem podia subir o morro e até que horas. Em plena cidade do Rio de Janeiro havia áreas onde o Estado não entrava e a população mais pobre da cidade era refém de traficantes e milícias fortemente armadas. (Beltrame, SSP/RJ)

A ideia, portanto, desde o início, não era acabar com o tráfico, mas retomar os territórios para o Estado. A reterritorialização dos espaços sob o domínio do tráfico era o primeiro passo para que se conseguisse "entrar para ficar". Desta perspectiva, "entrar para ficar", é que a história da "segurança cidadã" toma um novo rumo e refaz seu caminho para instalar as Unidades de Polícia Pacificadora (UPPs).

As falas anteriores do secretário Beltrame, também, deixam evidente os primeiros momentos do PES, onde o gestor define qual é a "explicação verdadeira" para o fenômeno e como, a partir dessa leitura de cenário, ele pretende agir. Por isso, para Matus (1996), a simples mudança de gestor já altera o jogo, pois é a visão pessoal que o gestor tem do jogo e de como os jogadores se movimentam que vai guiar suas ações. Conforme destacado por Matus (1996), tanto melhor será o gestor público, quanto maior for a sua capacidade de compreender o jogo e os diversos interesses dos jogadores.

O secretário de Segurança Pública, José Mariano Beltrame, afirma que,

no começo, colocar o nome UPP foi uma briga. Colocar a palavra "pacificação" foi um grande problema porque ia parecer que o Rio estava em guerra. Daí eu disse: gente, se vocês não se convencerem que estas ilhas de violência fazem parte do estado do Rio de Janeiro, nós não vamos resolver isso. Nós estamos em guerra, sim. Primeiro é preciso reconhecer isso. Não é para agir como se aquelas áreas não fossem o Rio de Janeiro. Aquela é uma área que é de guerra e é o Rio de Janeiro. Isso, vocês (governador e demais secretários do Estado do Rio de Janeiro, em reunião) têm que assimilar e têm que tratar isso como guerra. Só reconhecendo o que está acontecendo, reconhecendo que há 
uma guerra no Rio de Janeiro que vamos poder começar a tratar do problema. O ponto número 1 é entender e tomar consciência da situação. O Estado também tinha que reconhecer que a polícia tem problemas, que tem este monte de vícios por causa da guerra, porque ela foi treinada pra fazer a guerra e não para prestar serviço.

Como já destacado por Matus (1991), a utilização do PES exige essa compreensão da realidade, "encará-la de frente e sem qualquer maquiagem". Antes de tentar resolver um problema, "é indispensável precisar o seu conteúdo". O nome do problema não pode ser ambíguo de modo que o gestor "corra o risco de tentar explicar ou resolver três ou quatro problemas diferentes assumindo que é um só" (Matus, 1996:23). As entrevistas com o secretário de Segurança, Mariano Beltrame, dão amostras dos processos organizacionais que antecederam as instalações das primeiras UPPs, onde pode ser localizado cada um dos momentos do PES, e mostram a dificuldade dos governantes em reconhecer e declarar publicamente a existência de um problema.

Mas voltemos ao começo, à história das UPPs, na perspectiva do gestor responsável pela sua implantação, o secretário de Segurança Pública, José Mariano Beltrame.

Eu digo que a UPP é muito mais da intenção ao gesto, do que construir isso como uma tese, um plano. Eu pensava o seguinte: eu preciso, em quatro anos, mostrar que a gente pode fazer, que é possível e que a gente sabe fazer. Se eu fosse desenhar isso, escrever isso, fazer um plano, eu não faria isso em um só mandato de governo. Até porque, depois de fazer o plano, eu ia precisar de outro mandato de governo para vender a ideia e depois mais outro para realizar a logística para colocar o plano em ação. (Beltrame, SSP/RJ)

Nesta fala "a UPP é muito mais da intenção ao gesto do que construir uma tese, um plano", o secretário sinaliza tanto a urgência em buscar resolver um problema que vem se avolumando na cidade do Rio de Janeiro, quanto uma vontade que vai diretamente ao fazer ou, ao "fazimento", nas palavras de Darcy Ribeiro. Uma expressão que enfatiza que as ideias devem caminhar de mãos dadas com a ação; que enfatiza, também, ação, reflexão e ação, pois também podem ser necessários "refazimentos" (Ribeiro, 1997).

Agora, o que se planejou foi o seguinte: como entrar e ficar? Como é que você vai fazer isso? Então, foi o que a gente fez: pensou em como ia entrar para ficar.

Nos primeiros meses, a gente (equipe de segurança pública) analisou a cidade como um todo e via que ela era manchada, ela era tipo um tabuleiro de xadrez. Tinha lugares no Rio de Janeiro que eram ilhas de pura violência, de exclusão. Uma ditadura imposta pelo crime, tráfico ou milícia e que não tinham a presença do Estado. Quanto maior a ausência do Estado maior a criminalidade, a violência e a exclusão social. (Beltrame, SSP/RJ)

A fala anterior do secretário de Segurança Pública espelha o momento explicativo de Matus (1996), pois o autor também destaca que trabalhar com problemas significa: explicar 
como nasce e se desenvolve um problema; é, exatamente, o primeiro passo: buscar descrever o problema assinalando os fatos que mostram sua existência.

Então, primeiro, a gente mapeou os complexos. Nós pegamos 40 grandes complexos de favela. Quando a gente fala em Rocinha, é Rocinha, Vidigal e Chácara do Céu. Não adianta você tomar a Rocinha, se os caras pulam para o Vidigal. E assim, vai. Não adianta ocupar a Nova Holanda, se não ocupar a Baixo Sapateiro e todas as outras que compõem a Maré, por exemplo. A Tijuca tem 17 morros e ali você tem as três faç̧ões. Por isso as balas traçantes. É um brigando com o outro. Não é com a polícia. A polícia é um ingrediente nessa luta. A Rocinha correu o mundo inteiro por quê? Era o Bem-te-vi, um dos chefes do tráfico, que queria tomar não sei o que de não sei quem. Mas o que eles queriam, mesmo? O que eles queriam na briga entre Vidigal e Rocinha? Mercado, território. Eles estavam ali atrás de pontos de venda de drogas. (Beltrame, SSP/RJ)

Para Matus (1996) não há como planejar sem antes fazer esse reconhecimento percebido na fala do secretário de Segurança Pública. Em outros termos, a metodologia do PES exige o conhecimento da realidade. Não há sequer como pensar em planejamento sem conhecer a realidade para que seja possível começar a pensar em como atuar considerando todos os atores/jogadores envolvidos. O objeto da disputa deve ser claro, como neste caso, o território.

Nós tínhamos a ideia de chegar para ficar em uma comunidade dominada pelo tráfico mais ou menos alinhavada, mas eu disse: "Não dá pra escrever isso aí. Nós vamos ficar um ano aqui sem dar uma resposta concreta, só para eu colocar no papel o plano para o governador, para convencer ele 'comprar' a ideia". Então, na época, eu disse "vamos pra dentro de um lugarzinho pequeno, fazer um teste. Não vou eu me arvorar a ocupar a Cidade de Deus, por exemplo. Vamos pequenininho". (Beltrame, SSP/RJ)

Metodologicamente, este momento pode ser entendido com a de concepção do plano, de identificação de quais ações poderiam ser postas em prática para enfrentar os problemas. Matus (1991) lembra que os planejadores eficazes não são aqueles que se abstraem dos detalhes do dia a dia, mas o contrário: são os que neles imergem e são capazes de descobrir o momento certo de agir. É preciso haver união entre pensamento e ação.

$\mathrm{O}$ que aconteceu foi que do momento ainda de concepção do plano se passou à ação. Aconteceu de repente.

Eu vi uma oportunidade porque conhecia a realidade Morro Santa Marta. Em dezembro de 2008, tinha tido uma operação policial grande ali e o resultado foi que o Dona Marta ficou meio acéfalo. As lideranças do crime foram presas e seu principal líder foi morto no conflito com a polícia. Então, eu disse para o meu pessoal: "é agora ou nunca. Vamos aproveitar a oportunidade ou, então, vai aparecer outro para assumir o papel de líder da comunidade" Fomos para o Morro Santa Marta, entramos lá e conseguimos ocupar uma antiga creche que era da Prefeitura e o tráfico não deixava a comunidade usar. Mas era aquela coisa: nós não tínhamos policiais novos pra botar lá, policiais 
preparados com uma política de proximidade. Foram os policiais do Batalhão, selecionados pelo Comandante. Foi uma coisa improvisada e o improvisado deu certo. Os índices de criminalidade lá dentro diminuíram. Eu estou há mais de quatro anos no Morro Santa Marta, sem nenhum homicídio. (Beltrame, SSP/RJ)

Estas falas do secretário Beltrame mostram que "o suporte essencial para tomar uma decisão no jogo é o julgamento do apostador, fundamentado, em parte, por cálculos parciais bem-estruturados e, em parte, por suas preferências explícitas" (Matos, 1991:30). A ocupação do Morro Santa Marta é, tipicamente, a espiral do método PES. O momento estratégico, de agir a partir "do que pode ser feito", utilizando as estratégias e recursos disponíveis naquelas circunstâncias, coincide com o momento tático-operacional. Em outros termos, "saber fazer no momento oportuno e com eficácia, recalculando e completando o plano com um componente de improvisação subordinada" (Matus, 1991:31). O Morro Santa Marta fica no bairro de Botafogo, Zona Sul do Rio, foi o primeiro a receber uma UPP, em 19 de dezembro de 2008. Trata-se da primeira experiência de "polícia de proximidade", policial-servidor, da Secretaria de Segurança Pública do Estado do Rio de Janeiro. A unidade opera, desde então, com 112 policiais que foram preparados em um curso de especialização para aprenderem a trabalhar junto e para a comunidade. A ideia é diminuir cada vez mais a polícia ostensiva e levar para a comunidade a polícia comunitária.

Assim começou a UPP: a milícia chefiada pelo Nick sequestrou um repórter lá no Morro Santa Marta. Prendemos o Nick, a favela ficou acéfala. Vamos pra lá. O pessoal perguntou: “de que jeito?”. Só respondi "vamos pra lá. Não vamos perder tempo". E o nosso projetinho aqui saindo. Nosso plano ainda tava saindo. A gente ainda tava pensando como botar isso no papel, mas vimos que era a hora de ocupar o Morro Santa Marta, era o momento, a gente não podia perder aquela oportunidade. Aí, a gente entrou e levou o Batalhão de Bangu. O Batalhão ficou uns 30 dias. A gente começou a trabalhar lá mesmo sem estrutura. (Beltrame, SSP/RJ)

Isso acontece porque o gestor (jogador), no jogo social real, não pode escolher as circunstâncias para realizar o que foi planejado. O plano deve ser constantemente adequado ao contexto. Na realidade, "um plano só se completa na ação, nunca antes. É na improvisação tática da ação que completa-se o conteúdo prático do plano". Do mesmo modo, "a velocidade do fazer, exigida pela velocidade dos acontecimentos é um sério desafio" para os gestores (Matus, 1991:40). Nesse caso, é preciso lembrar que, para Matus (1991:39), a improvisação subordinada "é um cálculo situacional oportuno que supera facilmente a planificação tradicional, que é tecnocrática e lenta". Portanto, a improvisação serve ao plano e, ao mesmo tempo, faz parte dele. Para o PES, a improvisão é subordinada ao plano, pois faz parte do jogo trabalhar com cenários possíveis da realidade, e tanto melhor será o jogador quanto maior sua capacidade de imaginar possíveis cenários nos quais possa atuar.

No início éramos eu e ela [a esposa do Secretário de Segurança estava presente na hora desta entrevista] no Morro Santa Marta. Tudo que acontecia no Santa Marta era porque eu e Rita [a 
esposa] fazíamos. Ela levava até coisas assistencialistas, no sentido de tentar apaixonar as pessoas pela polícia. A gente conseguiu colocar uns médicos. Então, éramos eu, o Batalhão de Bangu e minha esposa. Não houve apoio do Estado porque o Estado não sabia se ia dar certo. Mas nós vimos uma oportunidade e não podíamos perder. Foi quando eu comecei a falar em outros departamentos do governo. Eu dizia: "gente, isso aqui tem que funcionar. A Segurança Pública veio e integrou o território. O Estado pode ir lá, agora. Se não vier o resto do Estado para atender à demanda social, não vai ser a polícia que vai segurar. Vai voltar a ser tudo como era antes. Era preciso se envolver com a comunidade. Prover equipamentos e serviços públicos, mas sem tirar a autonomia da comunidade. Mas enquanto o restante do Estado não estava convencido que esta ação poderia dar certo, não veio ninguém". (Beltrame, SSP/RJ)

Lembramos que, para Matus (1996), tanto melhor será o planejador (jogador) quanto maior for sua capacidade de compreender o jogo e os diversos interesses dos jogadores, quanto maior for seu conhecimento da realidade e de como operam os jogadores. Só foi possível determinar que aquele era o momento de ocupar o Morro Santa Marta porque a dinâmica social daquele contexto era conhecida. Mas também era preciso convencer outros jogadores, possíveis aliados, a participar do jogo. Esses possíveis aliados, outros gestores públicos, no entanto, não foram convencidos das possibilidades de o plano dar certo. Por isso mesmo, não houve apoio formal do governo do estado.

Para Matus (1996:77), "poder político e eficácia estão fortemente inter-relacionados" e, nesse caso, o medo da ineficácia do plano parece ter sido maior do que a vontade de implementá-lo, pois a ineficácia do plano poderia levar à perda de poder político do governo do estado. Em outras palavras, possivelmente, o receio de perder poder político levou o governante a não apoiar a operacionalização do plano, a princípio, como no caso das UPPs no Rio de Janeiro.

Daí a necessidade de o plano ser dual. Isto é, o plano deve distinguir aquela parte que está totalmente sob a governabilidade do jogador, no caso, do gestor responsável pela implantação das UPPs, daquela na qual se requer a cooperação de outros atores para alcançar as metas propostas. Entretanto, há que se destacar que essa segunda parte do plano é composta de demandas e denúncias. As demandas podem não ser incialmente atendidas, mas quando a absoluta falta de cooperação se manifesta, em determinadas condições, o plano se transforma em um plano de denúncias (Matus, 1996:48). O que aconteceu quando o secretário começou a convocar as demais Secretarias do estado a se envolver e prestar serviços às comunidades já pacificadas e, de certa forma, a exigir do próprio governador que tomasse providências quanto às comunidades já pacificadas.

\subsection{0 planejamento foi sendo realizado junto com a ação}

Nesse meio tempo, o Comandante de Jacarepaguá, onde fica localizada a Cidade de Deus disse: "Secretário, vamos ocupar a Cidade de Deus". Foi uma ação até meio descolada da gente que estava no 
Morro Santa Marta, mas a situação, naquele momento, era parecida com o do Morro Santa Marta quando resolvemos ocupar. Ele foi, ocupou e deu certo. Eu disse: "Nós não temos como voltar atrás, certo?". Então, fui lá e dei apoio. Logo depois, fomos para o Morro do Batan, em Realengo. Também foi uma oportunidade que não podia ser perdida. Igual ao Morro Santa Marta, o tráfico no Batan também tinha perdido a liderança e estava se reacomodando. Então, nós fomos pra lá e também não saímos mais. Aí, depois as coisas começaram a se ordenar. Conversei com o pessoal e disse "agora é hora de organizar um pouco disso no papel. Hora de voltar para o projetinho, para escrever o que nós estamos fazendo". (Beltrame, SSP/RJ)

A entrada da polícia nas comunidades Dona Marta, Cidade de Deus e Batan é expressão concreta do PES: uma combinação de cálculo e apostas realizadas com base no conhecimento da situação, da dinâmica da realidade e dos atores/jogadores com interesse no jogo. Como afirmado por Matus (1996), o plano é uma aposta, embora para alguns possa parecer falta de sistematização. Então, é preciso lembrar que, ao se tomar a realidade na elaboração de um plano, o resultado não depende somente do próprio plano, depende, também, das circunstâncias que não são controláveis e nem possíveis de predizer.

A ocupação da Cidade de Deus para a retomada de território pelo comandante de Jacarepaguá, além de indicar que havia um conhecimento prévio da dinâmica social daquela comunidade, também evidenciou para o secretário Beltrame a existência de outros jogadores com os mesmos interesses nesse jogo social. De acordo com Matus (1996), a construção dessa matriz de afinidades é fundamental para a operacionalização e viabilização do plano, pois aumenta sua probalidade de êxito. No entanto, como assinala o autor, ao mesmo tempo que se somam as forças requeridas para a viabilidade das operações, o conteúdo dessas operações também precisa ser ajustado às necessidades dessas alianças que propiciaram o apoio ao plano. Como deixou claro na sua fala o secretário Beltrame, já buscando evitar que houvesse uma pulverização e consequente fragilização do plano:

"agora é hora de organizar um pouco disso no papel. Hora de voltar para o projetinho, para escrever o que nós estamos fazendo". As coisas começaram a se ordenar. Deixamos de entrar em determinadas comunidades só porque víamos uma oportunidade. Porque ninguém podia dar conta daquilo sozinho. A polícia vai fazer o quê sem o restante do Estado? Vai entrar e sair. Ia repetir o mesmo de sempre. A gente tinha que entrar e as outras secretarias tinham que vir atrás. Depois da Cidade de Deus, eu vi que, se não houvesse um engajamento forte, nossas ideias e ações não tinham como se sustentar. Nós precisávamos do apoio do Estado inteiro. Aí, fui ao governador e disse: "O senhor precisa reunir os secretários, prefeitura e nomear um responsável pelo que não é papel da polícia". Pelo menos, mais 40 comunidades necessitam deste mesmo tipo de ação. E a cidade inteira, que todo dia tem uma coisa. "O senhor precisa nomear um articulador." Daí, o governador criou a Unidade de Polícia Pacificadora Social e nomeou o Ricardo Henriques [Coordenador da UPP Social - uma unidade que representa a união entre o estado e a prefeitura do Rio de Janeiro no atendimento às demandas sociais da população] como articulador e eu fui me despojando. Foi aí que o governo do Rio de Janeiro começou a apoiar, de fato, uma ideia que já estava em andamento, que já havia 
sido concretizada em três favelas do Rio de Janeiro e, principalmente, uma ideia que estava dando certo. (Beltrame, SSP/RJ)

As falas anteriores do secretário Beltrame e as consequentes ações do governo estadual mostram a eficácia da dualidade do plano, na perspectiva matusiana, ou seja, para obter a cooperação dos demais atores foi necessário denunciar a sua inexistência. "No plano dual, a aposta é dupla. Aposto no êxito de minha ação e aposto no êxito de minhas demandas e denúncias. A confiabilidade do plano também inclui, por consequência, a dosagem na qual se combinam esses dois aspectos do plano situacional" (Matus, 1991:41).

Hoje, quando eu me sinto só, eu vou atrás dos caras e digo "tá faltando Estado ali". Quando a UPP Social veio, foi o Estado que foi chegando para atender à demanda social. Aí, começou a entrar creche, escola, posto de saúde. Às vezes, até tinha os equipamentos, os prédios, mas não funcionavam. Então, o Estado veio e botou pra funcionar. Está muito melhor do que estava. Foi assim que começamos as UPPS, oficialmente: quando o governo viu que a iniciativa junto às comunidades estava dando certo, começou a apoiar. Quando os índices de criminalidade começaram a cair, teve boa repercussão na mídia. Quando o governador viu que as ações estavam obtendo resultados, então, ele também começou a pressionar e cobrar da equipe de segurança pública. Ele queria ver toda a cidade com UPP. Quando o filho é bonito todo mundo quer ser pai, não é? Então, hoje, se dependesse da decisão do Estado, nós criaríamos uma UPP por mês nas comunidades carentes. Mas não é assim, não. Tem ir de pouquinho, não pode se arvorar. Tem que primeiro conhecer bem a comunidade e quem atua por lá, tem que conhecer a dinâmica de cada comunidade. (Beltrame, SSP/RJ).

Este é um momento de ajustes entre o formal e o informal, momento de planejar a partir dos resultados das ações que parecem mais informais. Também é um momento estratégico, aquele de enfrentar e analisar a viabilidade do plano, do que já está sendo feito, sua viabilidade política, de descobrir o "que mais poder ser feito" e "como fazer", de buscar identificar estratégias que poderão ser utilizadas. Nesse caso, para que fosse possível dar continuidade às UPPs, foi necessário rever a Polícia do Estado do Rio de Janeiro, rever o currículo e o tipo de treinamento oferecido aos policiais.

Aí, nós percebemos que tínhamos outro problemão nas mãos. Como é que vamos colocar uma polícia de proximidade se só temos polícia que faz a guerra? O policial não foi preparado para fazer polícia comunitária. A Academia ensina a fazer guerra. Então, nós começamos uma preparação especial de polícia de proximidade para poder colocar quem fosse treinado nas comunidades com UPPs. Começamos por reformular o currículo da Academia, para formar um policial-servidor, uma polícia de proximidade. A reforma do currículo da Polícia Militar durou um ano. Tão difícil quanto ocupar o Complexo do Alemão foi tentar mudar a cabeça da polícia. (Beltrame, SSP/RJ)

Esta também foi uma fase fundamental para dar prosseguimento ao plano e, ao mesmo tempo, também é resultado de um plano elaborado no momento da própria ação. Foi um momento de obter apoio, agora, para mudar a formação da polícia. 
Foi um tempo de nos apoiarmos em outras lideranças que estavam surgindo, inclusive dentro das comunidades já ocupadas. Enquanto buscávamos apoio das universidades para mudar o currículo da Polícia Militar, os líderes das comunidades com UPPs buscavam apoio dos moradores. Já sabíamos que os planos que não tiveram sucesso em anos anteriores tinham uma variável em comum: a polícia não trabalhava em parceria com a população. Em experiências passadas, a polícia apenas vigiava os moradores das comunidades. Agora, já sabíamos que para o Estado entrar e ficar era preciso trabalhar com as comunidades. (Beltrame, SSP/RJ)

A fala do secretário chefe da Casa Civil, Régis Fischer, corrobora a fala do secretário de Segurança Pública:

quando já estávamos no Morro Santa Marta, na Cidade de Deus e no Batan, nós pensamos: "estamos fazendo uma coisa diferente aqui. Mas o que podemos fazer para que tudo possa dar certo?”. Aí, tivemos a oportunidade de fazer um treinamento com poucos policiais no Batan, lá com o Beltrame. Mas aí, veio o drama seguinte, quando a gente pensou: "como é que a gente vai fazer para dar certo em uma escala que realmente inverta a curva de criminalidade no Rio de Janeiro?”. Quando nós analisamos a questão, nós vimos que nosso problema era como colocar policiais novos porque o Centro de Formação da Academia de Polícia (Cefap) não tinha capacidade para isso, formar a quantidade de pessoal que precisávamos. Aí, começamos a encontrar os gargalos. Outro problemão: sabe como o Cefap funcionava? Por incrível que pareça, dar aula, formar policiais, ser instrutor de quem tava chegando era quase um castigo. O servidor da segurança pública que cometia algum deslize ou fazia alguma coisa errada, a punição era ir ao Cefap, situado na Zona Oeste, bem distante do centro da cidade do Rio de Janeiro. Era isso, mesmo! O mau policial era retirado das ruas e designado pra dar aula no Cefap. Era um policial com conduta duvidosa, na maioria das vezes, que ministrava aulas aos novatos. Por aí já se percebe o tipo de formação obtida pelos novos membros da Polícia Militar.

O ponto-chave do momento tático-operacional, nesse caso, da concretização das UPPs consiste em compreender que o planejamento é o resultado de uma mediação entre o conhecimento e a ação. Como destaca Matus (1996:104), trata de "recalcular o plano e de aprimorá-lo de acordo com as circunstâncias do momento da ação e do detalhe operacional que a prática exige". Trata-se do "refazimento" do plano, de colocar em prática novas ideias, refletir sobre elas e refazê-las de uma maneira melhor.

Esse, também, foi um momento de experimentar a coprodução, "entendida como estratégia de aproximação entre Estado e sociedade ou certa comunidade, ensejando à mesma a possibilidade de participar", da definição e construção de um bem de interesse público, em certo contexto, coletivamente (Shommer et al., 2010:4). Isso aconteceu especialmente quando o Estado buscou apoio das universidades locais para ajudar a mudar o currículo da Polícia Militar, bem como os líderes das comunidades com UPPs que poderiam apoiar e fortalecer essa iniciativa do Estado junto aos demais moradores.

Há que se destacar que o fenômeno da coprodução demanda a compreensão de outro conceito: o interesse público. No entanto, Denhardt e Denhardt (2007:67) entendem que 
tentar definir o interesse público é como tentar definir o amor: "está claro que o amor significa diferentes coisas para diferentes pessoas em diferentes circunstâncias". Assim, para esses autores, no máximo, se pode entender o interesse público como um processo para estabelecer uma direção ou um futuro desejado para a sociedade mediante o desenvolvimento de um conjunto de ideias (ou ideais) orientadores desse futuro. Ainda, é preciso lembrar que a coprodução de um bem público compreende uma ação conjunta e esta "implica não apenas consenso, acordo e confiança como pressupostos para a cooperação, mas também conflitos, disputas e articulações negociadas entre os diferentes sujeitos em cena" (Rocha et al., 2012:6). Como tem acontecido após cada uma das ocupações que resultam na instalação de uma nova UPP em uma comunidade do Rio de Janeiro.

Segundo o secretário de Segurança Pública,

não existe uma ocupação igual à outra e nunca vai ter um manual que me diga exatamente como fazer. Até a postura do policial tem de ser diferente. Então, para entrar e ficar em cada uma destas comunidades não é do mesmo jeito. Tem que ter uma maneira para cada uma. Não dá pra repetir como receita de bolo. É mais ou menos a mesma coisa, mas também não é. Claro, usa os policiais, vai com apoio até do exército já foi preciso, mas a maneira de chegar é diferente, as pessoas são diferentes, nos recebem de maneiras diferentes, o ambiente é outro, e tudo isso conta, alguns se fecham, outros vão para as ruas. É isso aí, não dá para ter um manual que me diga o que fazer na Maré ou no Vidigal ou em qualquer outra. (Beltrame, SSP/RJ)

Pensar diversas maneiras de ocupar o território, devido às peculiaridades de cada um, mostra a própria metodologia do PES, um planejar de acordo com a situação. Para Matus (1996), também não há uma única maneira de fazer um plano porque ele depende das características da realidade à qual se quer aplicá-lo. O PES leva em consideração que determinada situação-objetivo também está condicionada a cenários e ocorrências indeterminadas porque a realidade não é previsível.

Tenho que admitir, no início, a gente não fez o projeto, a gente não fez um plano, nem treinou novas lideranças, nem deu tempo. Nós fizemos tentativas. Um "plano", mesmo, um plano escrito, só foi elaborado quando começamos a pensar em criar uma UPP na Rocinha (Beltrame, $\mathrm{SSP} / \mathrm{RJ})$. Mas, na perspectiva matusiana, "nada é mais importante que a sequência como método para aproximar-se do objetivo em sistemas de incerteza inexorável” (Matus, 1991:41), ou seja, a implementação das UPPs está alinhada com a metodologia do PES. Na realidade, para Matus (1991:41), o plano faz parte da metodologia, ele não é anterior a ela e, também, "não é um anúncio de meios e resultados fundamentado em cálculos científicos certos". Isso porque "nenhuma técnica de planificação é segura diante da incerteza do mundo real e devemos nos apoiar em nossa capacidade para acompanhar a realidade" (Matus, 1991:40). Exatamente o que foi percebido no processo de implementação das UPPs no Rio de Janeiro, a partir das percepções e reflexões do secretário de Segurança Pública do Estado. Como destacado ao longo do texto, o PES, como método, "deve ser compreendido como um processo de aprendizagem-correção-aprendizagem, que força a realizações de correções permanente dos 
rumos das ações definidas" (Adum e Coelho, 2007:2). Em outros termos, a essência do PES é o acompanhamento permanente da realidade e a avaliação dos resultados das decisões tomadas e preteridas com objetivo de verificar se os resultados produzidos estão na direção dos resultados esperados. É o que tem sido realizado desde a primeira UPP. Talvez, não com um plano formalizado como no planejamento tradicional ou normativo, mas um planejamento, cuja metodologia leva em consideração a realidade, a situação de cada comunidade.

Enfim, com o sucesso da primeira UPP, instalada na comunidade do Morro Santa Marta, em Botafogo, em novembro de 2008, o governador do Rio de Janeiro formalizou a existência da "Unidade de Polícia Pacificadora" (UPP) por meio do Decreto no 41.650, de 21 de janeiro de 2009. Em junho de 2014, já são 38 UPPs com mais de 1,5 milhão de pessoas beneficiadas diretamente, em 264 territórios retomados pelo estado com 9.543 policiais com treinamento de polícia de proximidade, e o plano é implementar 50 UPPs até 2016 (UPPRJ-Governo do Estado do Rio de Janeiro, 2014:1).

\section{Considerações finais}

Trabalhar com o Planejamento Estratégico Situacional (PES) é, mais ou menos, como dar os primeiros passos para a compreensão de que "os homens fazem sua própria história, mas não a fazem como querem; não a fazem sob circunstâncias de sua escolha e sim sob aquelas com que se defrontam diretamente" (Marx, 1997:21). Há que se acrescentar que os homens também agem a partir de certas perspectivas. Como assinala Matus (1991, 1996), é possível imaginar, compor um feixe de possibilidades, participar da história, mas não é possível definir seu destino. Este é o caso das UPPs: elas são verdadeiras organizações em processo e cujo sucesso depende do engajamento cada vez maior do Estado, da sociedade e, principalmente, das comunidades onde estão instaladas. Sem essa participação ativa, a história indica que nada impede que as zonas de guerra sejam retomadas no Rio de Janeiro.

O caso das UPPs mostra que, quem trabalha com o PES, trabalha com a noção de sistema real, pois são nestes sistemas reais que vivemos em nossa prática social. É o que Matus (1996) denomina "sistema de incerteza dura". É um modelo que reconhece que há uma assimetria entre passado e futuro. O passado está encerrado, tudo o que era possível já aconteceu; o futuro está aberto a muitas possibilidades e não podemos imaginá-las todas. Mas podemos ser criativos! Podemos enumerar possibilidades futuras; nunca todas. E, mesmo com toda incerteza, é nesta realidade que o gestor público deve governar.

O que se observou, também, ao longo da pesquisa, ouvindo as narrativas do secretário de Segurança Pública, José Marino Beltrame, é que as ações implementadas no sentido de concretizar as UPPs tiveram origem na Secretaria de Segurança Pública, com inserções isoladas em comunidades dominadas pelo tráfico, que passaram a ser, institucionalmente, reconhecidas quando a própria sociedade civil começou a se manifestar a favor das UPPs. Principalmente, quando os índices de criminalidade começaram a diminuir nas regiões onde foram instaladas as UPPs. 
Constatou-se que a história das UPPs relaciona-se com a presença ou ausência de lideranças dentro e fora das favelas. Os primeiros territórios recuperados pelo Estado foram retomados porque a liderança do tráfico na região foi morta ou, como afirmado anteriormente, foi um momento em que a favela ficou acéfala e as pessoas ainda estavam se reorganizando. Foi nesse momento que a liderança da Secretaria de Segurança Pública, percebendo a acefalia, entrou e retomou para o Estado um território sob o controle do tráfico e das milícias há mais de 20 anos. Em uma perspectiva matusiana, "o líder é o que vê mais além da esquina, mas só é estadista aquele que enxerga mais além da estrada", e "a grande estratégia não é um jogo contra outros jogadores conhecidos, mas contra o óbvio, o rotineiro e o legitimado". Nesse sentido, as UPPs, na metodologia do PES, representam o resultado de uma aposta de um estadista contra o óbvio.

Nessa mesma perspectiva metodológica, mesmo com 38 UPPs já instaladas na cidade do Rio de Janeiro, é natural que cada uma delas resulte de uma experiência diferente na relação entre os agentes, especialmente no interior das comunidades, em que o papel de suas próprias lideranças contribuiu de maneira distinta tanto para a retomada do território quanto para a construção da realidade emergente. Trata-se de lutas territoriais e cada território retomado pelo Estado representa uma luta, às vezes armada, com os líderes que dominavam as comunidades pela força. Em outros termos, a implementação de cada UPP, na metodologia do PES, exige uma apreciação e uma explicação situacional. "A apreciação situacional de cada jogador é o motivo e o motor de sua ação" (Matus, 1991:33). Isso explica, por exemplo, por que em algumas comunidades houve resistência quando da implementação das UPPs. Os jogadores (milícias e traficantes) daquela área apostaram que o Estado não enfrentaria a resistência. Uma apreciação equivocada, posto que, para o Estado, o não enfrentamento poderia culminar no surgimento de novas resistências, inclusive, em áreas em que já existem UPPs, como tem acontecido esporadicamente.

Nas primeiras retomadas de territórios a luta armada era forte e frequente e, por isso mesmo, era necessário reunir as polícias e o exército para subir os morros em ações que surpreendiam os moradores das comunidades. À medida que as UPPs ganharam o apoio da sociedade e se configuraram como uma política de segurança pública, as ações da Secretaria de Segurança Pública também mudaram e passaram a ser estruturadas a partir de uma metodologia na qual as intervenções passaram a ser comunicadas antecipadamente, a ponto de nas últimas ações para retomada de territórios não ter sido disparado um tiro sequer.

A reestruturação dos programas de formação de policiais foi fortemente influenciada pelas UPPs na medida em que se estabeleceu como objetivo central preparar os novos agentes para agir como polícia comunitária e não como polícia de guerra.

Os efeitos positivos da libertação dos territórios, anteriormente dominados pelo tráfico, vêm sendo reconhecidos pelas comunidades inseridas nos morros, que demandam do governo que na sua região seja implantada uma UPP.

É preciso lembrar, entretanto, que é necessário evitar que seja criada uma nova situação de dependência nas comunidades, ou seja, os novos líderes comunitários devem surgir dentro da própria comunidade e não substituir a liderança do tráfico e das milícias pela liderança da 
polícia. Não reconhecer a capacidade de auto-organização da comunidade local pode significar a criação de novas situações de dependência, ao invés de independência e cidadania.

Isto significa dizer que é preciso ficar atento tanto à participação da polícia na vida da comunidade cujo território foi retomado pelo Estado, quanto ao nível de participação real dessa comunidade nas decisões acerca do seu território. Caso se perca essa perspectiva, teremos a mera substituição de uma liderança por outra, ao invés da comunidade decidindo seu destino.

A proposta de retomar os territórios para o Estado para que este possa oferecer nestas localidades os serviços de sua responsabilidade não pode ser substituída por uma ação na qual os representantes da polícia se tornem os líderes locais. Os representantes da polícia, das UPPs, apenas devem garantir que as comunidades tenham o direito de se organizar. Comunidade e Estado, cointencionados à realidade, se encontram numa tarefa em que ambos são sujeitos no ato, não só de conhecer a realidade, mas também no ato de recriá-la. Ou seja, comunidade e Estado se descobrem como refazedores permanentes da realidade, de modo que a presença da comunidade na busca de sua libertação, mais que pseudoparticipação, será o que deve ser: engajamento.

Finalmente, é preciso lembrar que, na metodologia matusiana, resultados obtidos não são resultados garantidos ad infinitum. À medida que atores sociais mudam ou muda a situação, novas explicações e ações são exigidas. Nesse caso, novos atores e novas leituras da realidade podem levar a novas ações que, potencialmente, transformarão o que está posto.

Talvez, a melhor maneira de encerrar este texto seja trazendo as perguntas que, rotineiramente, os atores de um jogo deveriam fazer, segundo Matus (1991:42): "para onde nos conduz essa incessante dinâmica? Qual a eficácia e a validade do objetivo que perseguimos? Como podemos imaginar nosso futuro? Como podemos verificar se as metas que para nós traçamos levam a algo de valor?”. Tais perguntas são necessárias porque, lembrando Marx (1997:21), a história só se repete "como farsa".

\section{Referências}

ADUM, José J.; COELHO, Gelda L. O Planejamento Estratégico Situacional — PES, na gestão pública: o caso da Prefeitura da Cidade de Juiz de Fora. Revista Eletrônica de Economia, Juiz de Fora, n. 9, p. 2-17, 2007. Disponível em: <www.viannajr.edu.br/revista/eco/down.asp?url=doc/artigo_90001. pdf $>$. Acesso em: 18 maio 2013.

ALBERTI, Verena. História oral: a experiência do Cpdoc. Rio de Janeiro: Contemporânea do Brasil, 1990.

ARTMANN, Elizabeth. O planejamento estratégico situacional no nível local: um instrumento a favor da visão multissetorial. Rio de Janeiro: Oficina Social, 2000. p. 1-24. Disponível em: < http://lms. ead1.com.br/upload/biblioteca/modulo_5429/5BCSTY9RH6.pdf>. Acesso em: 22 nov. 2014.

BATISTA, Soraya. Projeto Indústria do Conhecimento se mutiplica em áreas de UPPs. Governo do Rio de Janeiro, 2014. Disponível em: <www.upprj.com/index.php/acontece/acontece-selecionado/ 
projeto-industria-do-conhecimento-se-multiplica-em-areas-de-upps/Escondidinho\%20\%7C\%20 Prazeres>. Acesso em: 31 maio 2014.

BOM MEIHY, José C. S. (Re)introduzindo a história oral no Brasil. In: BOM MEIHY, José C. S. (Org.). (Re)introduzindo a história oral no Brasil. São Paulo: Xamã, 1996. p. 1-10.

CAPPELLE, Mônica C. A.; BORGES, Ceyça L. P.; MIRANDA, Adílio R. A. Um exemplo do uso da história oral como técnica complementar de pesquisa em administração. Anais do VI EnEO. Florianópolis: Anpad, 2010. p. 1-13.

DE TONI, Jackson. O que é o Planejamento Estratégico Situacional? Revista Espaço Acadêmico, Paraná, n. 32, p. 1-12, 2007. Disponível em: <www.espacoacademico.com.br/032/32ctoni.htm>. Acesso em: 28 maio 2014.

DENHARDT, Robert B.; DENHARDT, Janet V. The new public service: serving, not steering. Expanded edition. Nova York: M. E. Sharp, Inc. 2007.

FONSECA, João Carlos. Federações patronais promovem concorrida manifestação na Alerj em defesa do Sistema "S". Telebrasil, 2008. Disponível em: <www.telebrasil.org.br/sala-de-imprensa/ artigos/1402-federacoes-patronais-promovem-concorrida-manifestacao-na-alerj-em-defesa-dosistema-s>. Acesso em: 28 maio 2014.

LANA, Francisco C. F.; GOMES, Elizabeth L. R. Reflexões sobre o planejamento em saúde e o processo de reforma sanitária brasileira. Revista Latino-Americana de Enfermagem, Ribeirão Preto, v. 4, n. 1, p. 97-110, 1996. Disponível em: <www.scielo.br/pdf/rlae/v4n1/v4n1a09.pdf>. Acesso em: 23 nov. 2013.

LEHMKUHL, Claudete. Tecendo a paz social: estudo de caso do projeto "medalha de ouro - construindo convivência e segurança". Monografia (curso superior de Polícia da Polícia Militar de Santa Catarina com especialização lato sensu em gestão estratégica de segurança pública) — Universidade do Sul de Santa Catarina, Florianópolis, 2010.

LEITE, Márcia P. Entre o individualismo e a solidariedade: dilemas da política e da cidadania no Rio de Janeiro. Revista Brasileira de Ciências Sociais, v. 15, n. 44, p. 73-90, 2000. Disponível em: <www.scielo.br/pdf/rbcsoc/v15n44/4148.pdf>. Acesso em: 15 maio 2013.

LESSA, Carlos. O Rio de todos os Brasis: uma reflexão em busca da autoestima. Rio de Janeiro: Record, 2000.

MATUS, Carlos. O método PES. In: HUERTAS, Franco. O método PES: entrevista com Carlos Matus. São Paulo: Fundap, 1996. p. 1-139.

MATUS, Carlos. O plano como aposta. São Paulo em Perspectiva, v. 5, n. 4, p. 28-42, 1991. Disponível em: <http://webcache.googleusercontent.com/search?q=cache:https://www.seade.gov.br/ produtos/spp/v05n04/v05n04_07.pdf > e < http://ebookbrowsee.net/o-plano-como-aposta-carlosmatus-pdf-d371729066>. Acesso em: 8 jul. 2014.

MATUS, Carlos. Política, planejamento e governo. Brasília: Ipea, 1993. t. I e II.

MARX, Karl. O 18 brumário e cartas a Kugelmann. Rio de Janeiro: Paz e Terra, 1997. 
MINISTÉRIO DA EDUCAÇÃO (MEC). Protocolo de compromisso que entre si fazem o Ministério da Educação, o Ministério do Trabalho e Emprego, o Ministério da Fazenda, a Confederação Nacional da Indústria, o Serviço Nacional de Aprendizagem Industrial e o Serviço Social do Comércio, 2008. Disponível em: <http://portal.mec.gov.br/arquivos/pdf/protocolocni.pdf>. Acesso em: 28 maio 2014.

OLIVEIRA, Bruno. C. S. Reconhecimento, assimetrias e participação popular na gestão compartilhada do Programa de Aceleração do Crescimento (PAC) no Complexo do Alemão/RJ. Anais do III Seminário Nacional e I Seminário Internacional Movimentos Sociais Participação e Democracia. Florianópolis: UFSC, 2010. p. 1565-1579. Disponível em: <www.sociologia.ufsc.br/npms/mspd/ a097.pdf>. Acesso em: 6 abr. 2012.

RIBEIRO, Darcy. Confissões. Rio de Janeiro: Companhia das Letras, 1997.

ROCHA, Arlindo C. et al. A coprodução do controle como bem público essencial à accountability. Anais do XXXVI Encontro da Associação Nacional de Pós-Graduação e Pesquisa em Administração. Rio de Janeiro, 22 a 26 set. 2012. Disponível em: <www.anpad.org.br/diversos/trabalhos/EnANPAD/ enanpad_2012/APB/Tema\%2001/2012_APB556.pdf>. Acesso em: 8 jun. 2014.

SCHOMMER, Paula C.; BUENO, Rogério U. H.; KUNZLER, Rogério. Coprodução de serviços públicos e gestão de resíduos sólidos: caminhos e obstáculos na experiência de um município catarinense. Anais do IV Encontro de Administração Pública e Governança. Vitória (ES), 28 a 30 set. 2010. Disponível em: <www.anpad.org.br/diversos/trabalhos/EnAPG/enapg_2010/2010_ENAPG234.pdf>. Acesso em: 18 jun. 2014.

SISTEMA FIRJAN. Mapa do Desenvolvimento do Estado do Rio de Janeiro (2006-2015). Rio de Janeiro: Sistema Firjan, 2006. Disponível em: < file:///C:/Users/PPGE1/Downloads/mapa_ver1\%20 (1).pdf>. Acesso em: 31 maio 2014.

UPPRJ. Governo do Estado do Rio de Janeiro. Números. Disponível em: <www.upprj.com/> . Acesso em: 8 jun. 2014.

Joysi Moraes é doutora em administração, professora adjunta do Departamento de Empreendedorismo e Gestão da Universidade Federal Fluminense (UFF), do Programa de Pós-Graduação em Administração (PPGA/UFF/Volta Redonda) e do Programa de Pós-Graduação em Gestão e Empreendedorismo (PPGE/ UFF). E-mail: jmoraes@id.uff.br.

Sandra R. H. Mariano é doutora em engenharia de sistemas e computação, professora associada do Departamento de Empreendedorismo e Gestão da Universidade Federal Fluminense (UFF), do Programa de Pós-Graduação em Administração (PPGA/UFF/Volta Redonda) e do Programa de Pós-Graduação em Gestão e Empreendedorismo (PPGE/UFF). E-mail: sandramariano@id.uff.br.

Andrea Marinho de Souza Franco é mestre em sistemas de gestão pelo Programa de Pós-Graduação em Sistemas de Gestão da Universidade Federal Fluminense (UFF). E-mail: amarinho@firjan.org.br. 